\title{
Warming alters coupled carbon and nutrient cycles in experimental streams
}

\author{
Authors: Tanner J. Williamson, Wyatt F. Cross, Jonathan P. \\ Benstead, Gisli M. Gislason, James M. Hood, Alexander D. \\ Huryn, Philip W. Johnson, \& Jill R. Welter
}

This is the peer reviewed version of the following article: [Williamson, Tanner J., Wyatt F. Cross, Jonathan P. Benstead, Gisli M. Gislason, James M. Hood, Alexander D. Huryn, Philip W. Johnson, and Jill R. Welter. "Warming alters coupled carbon and nutrient cycles in experimental streams.." Global Change Biology 22, no. 6 (June 2016): 2152-2164.], which has been published in final form at https://dx.doi.org/10.1111/gcb.13205 This article may be used for noncommercial purposes in accordance with Wiley Terms and Conditions for Self-Archiving.

Williamson, Tanner J., Wyatt F. Cross, Jonathan P. Benstead, Gisli M. Gislason, James M. Hood, Alexander D. Huryn, Philip W. Johnson, and Jill R. Welter. "Warming alters coupled carbon and nutrient cycles in experimental streams.." Global Change Biology 22, no. 6 (June 2016): 2152-2164. DOI: https://dx.doi.org/10.1111/gcb.13205.

Made available through Montana State University's ScholarWorks scholarworks. montana.edu 


\title{
Warming alters coupled carbon and nutrient cycles in experimental streams
}

\author{
Tanner J. Williamson ${ }^{1}$, Wyatt F. Cross ${ }^{1}$, Jonathan P. Benstead ${ }^{1}$, Gisli M. Gislason ${ }^{3}$, James M. Hood ${ }^{1}$, Alexander D. \\ Huryn $^{2}$, Philip W. Johnson ${ }^{4}$, \& Jill R. Welter ${ }^{5}$ \\ ${ }^{1}$ Department of Ecology, Montana State University, Bozeman, MT 59717, USA, ${ }^{2}$ Department of Biological Sciences, University of \\ Alabama, Tuscaloosa, AL 35487, USA, ${ }^{3}$ Institute of Life and Environmental Sciences, University of Iceland, Askja, Sturlugata 7 , \\ 101 Reykjavik, Iceland, ${ }^{4}$ Department of Civil, Construction and Environmental Engineering, University of Alabama, Tuscaloosa, \\ AL 35487, USA, ${ }^{5}$ Department of Biology, St. Catherine University, Saint Paul, MN 55105, USA
}

\begin{abstract}
Although much effort has been devoted to quantifying how warming alters carbon cycling across diverse ecosystems, less is known about how these changes are linked to the cycling of bioavailable nitrogen and phosphorus. In freshwater ecosystems, benthic biofilms (i.e. thin films of algae, bacteria, fungi, and detrital matter) act as biogeochemical hotspots by controlling important fluxes of energy and material. Understanding how biofilms respond to warming is thus critical for predicting responses of coupled elemental cycles in freshwater systems. We developed biofilm communities in experimental streamside channels along a gradient of mean water temperatures $\left(7.5-23.6^{\circ} \mathrm{C}\right)$, while closely maintaining natural diel and seasonal temperature variation with a common water and propagule source. Both structural (i.e. biomass, stoichiometry, assemblage structure) and functional (i.e. metabolism, $\mathrm{N}_{2}$-fixation, nutrient uptake) attributes of biofilms were measured on multiple dates to link changes in carbon flow explicitly to the dynamics of nitrogen and phosphorus. Temperature had strong positive effects on biofilm biomass (2.8- to 24-fold variation) and net ecosystem productivity (44- to 317-fold variation), despite extremely low concentrations of limiting dissolved nitrogen. Temperature had surprisingly minimal effects on biofilm stoichiometry: carbon:nitrogen (C:N) ratios were temperature-invariant, while carbon:phosphorus (C:P) ratios declined slightly with increasing temperature. Biofilm communities were dominated by cyanobacteria at all temperatures ( $>91 \%$ of total biovolume) and $\mathrm{N}_{2^{-}}$ fixation rates increased up to 120 -fold between the coldest and warmest treatments. Although ammonium-N uptake increased with temperature (2.8- to 6.8-fold variation), the much higher $\mathrm{N}_{2}$-fixation rates supplied the majority of $\mathrm{N}$ to the ecosystem at higher temperatures. Our results demonstrate that temperature can alter how carbon is cycled and coupled to nitrogen and phosphorus. The uncoupling of $C$ fixation from dissolved inorganic nitrogen supply produced large unexpected changes in biofilm development, elemental cycling, and likely downstream exports of nutrients and organic matter.
\end{abstract}

Keywords: benthic biofilms, climate change, coupled biogeochemical cycles, ecological stoichiometry, metabolism, $\mathrm{N}_{2}$-fixation, nutrient uptake, temperature

\section{Introduction}

Global mean air temperatures rose $\sim 0.89^{\circ} \mathrm{C}$ in the twentieth century, with demonstrated effects on ecological structure and function across Earth's ecosystem types (Parmesan \& Yohe, 2003; IPCC, 2013). Like their terrestrial counterparts, freshwater ecosystems have shown clear warming trends (Adrian et al., 2009;
Kaushal et al., 2010), with associated changes in the physiology of individuals, structure of communities, and rates of ecosystem processes (Woodward et al., 2010). Considerable effort has been devoted to understanding how such warming is likely to alter carbon (C) cycling (Cox et al., 2000; Yvon-Durocher et al., 2010a) because the balance of anabolic (i.e. production) and catabolic (i.e. respiration) processes can drive feedbacks that may either exacerbate or slow the accumulation of $\mathrm{CO}_{2}$ in the atmosphere (Luo et al., 2004; Yvon-Durocher \& Allen, 2012). Much less attention, however, has been given to how C-cycle responses to warming may influence the flux and storage of other biologically important elements, such as nitrogen $(\mathrm{N})$ and phosphorus $(\mathrm{P})$, the cycling of which is coupled to C (Schlesinger et al., 
2011). Recent models and empirical work demonstrate that these coupled elements cannot be ignored (Hungate et al., 2003; Finzi et al., 2011; Cross et al., 2015).

How shifts in the $C$ cycle influence the dynamics of coupled nutrients should depend on how the demand for these nutrients changes with warming through (i) species-level physiological adjustments and/or (ii) patterns of species dominance and altered rates of ecosystem processes (Sistla \& Schimel, 2015). Predicted increases in $\mathrm{C}$ fixation rates with warming (e.g. YvonDurocher et al., 2010a) should drive changes in N and $\mathrm{P}$ demand that broadly reflect the C:nutrient stoichiometry (and potential demand) of primary producers. Because the elemental composition of autotrophs is potentially plastic, warming of nutrient-limited environments may lead to elevated autotroph C:nutrient stoichiometry (Frost et al., 2005; Sardans et al., 2012; De Senerpont Domis et al., 2014; but see Hall et al., 2005; Nifong et al., 2014), reduced relative nutrient demand, and increased nutrient use efficiency (UE; Rhee \& Gotham, 1981; Cross et al., 2015). Given no change in community structure, such stoichiometric responses to warming may modify how autotrophic $\mathrm{C}$ flux (e.g. gross primary production) is linked to the uptake and cycling of bioavailable $\mathrm{N}$ and $\mathrm{P}$ (e.g. nitrate- and ammonium-nitrogen and phosphatephosphorus in aquatic systems). Such an effect is also predicted if warming leads to broad shifts in community structure that favor taxa with elevated C:nutrient ratios, reduced nutrient demand, and relatively high nutrient UE (Cross et al., 2015).

Warming-induced changes in the activity and structure of autotrophic aquatic communities may also drive fundamental shifts in how nutrients are obtained from the environment and cycled. In N-limited ecosystems, warming can favor the abundance and activity of dinitrogen $\left(\mathrm{N}_{2}\right)$-fixing cyanobacteria, which typically exhibit high optimum growth temperatures (Paerl \& Huisman, 2008; Scott \& Marcarelli, 2012; but see Lürling et al., 2013) and steep temperature dependence for $\mathrm{N}_{2}-$ fixation (Ceuterick et al., 1978). These taxa can obtain $\mathrm{N}$ from gaseous $\mathrm{N}_{2}$, effectively decoupling C-based primary production from the dissolved ionic forms of $\mathrm{N}$ (e.g., ammonium, nitrate) utilized by non- $\mathrm{N}_{2}$-fixing taxa. If such changes in the source and routing of nutrients are ubiquitous, our understanding of how warming influences coupled element cycles will need significant revision (Finzi et al., 2011).

Here, we quantify the effects of warming on the coupling of $\mathrm{C}, \mathrm{N}$, and $\mathrm{P}$ cycling in experimental stream channels. Our small-scale experimental system provided a tractable framework for quantifying warming responses of stream biofilms, which represent hotspots of biogeochemical activity and contribute substantially to whole-system nutrient cycling and energy flux in lotic ecosystems (Lock et al., 1984; Battin et al., 2003). We first examined how warming influenced the biomass and elemental composition of biofilms. We predicted that warming would increase C-fixation rates, but reduce total biomass, consistent with metabolic scaling patterns (Brown et al., 2004; Allen et al., 2005; Yvon-Durocher et al., 2010b). We also predicted that warming this N-limited system (Friberg et al., 2009) would increase C:nutrient ratios, mediated by physiological adjustments within the community and elevated nutrient UEs. Alternatively, if warming enhances $\mathrm{N}_{2^{-}}$ fixation, eliminating progressive $\mathrm{N}$ limitation (Hungate et al., 2003), we would predict little change in biofilm C:nutrient ratios. Such a result would be driven by $\mathrm{N}_{2}$-fixation (and flux of $\mathrm{N}$ to the biofilm) keeping pace with C-fixation as temperatures increase.

We also examined how changes in biofilm biomass and stoichiometry were associated with relative rates of ecosystem processes (i.e. gross primary production, ecosystem respiration, $\mathrm{N}$ and $\mathrm{P}$ uptake, and $\mathrm{N}_{2}$ fixation) and element coupling. We predicted that temperature dependent patterns of $\mathrm{N}$ and $\mathrm{P}$ uptake would reflect shifts in biofilm stoichiometry, with little change across the thermal gradient as a result of increased C:nutrient ratios. However, if $\mathrm{N}_{2-}$ fixers are favored by warming, we expected that $\mathrm{N}$ demand by autotrophs would shift from heavy reliance on dissolved inorganic forms of $\mathrm{N}$ to dissolved $\mathrm{N}_{2}$ gas, effectively decoupling C-fixation from bioavailable inorganic $\mathrm{N}$. This could translate to previously unpredicted $\mathrm{C}$ cycling dynamics under future, presumably warmer, climates.

\section{Materials and methods}

\section{Site description}

Our study was conducted in the geothermally active Hengill area of southwestern Iceland $\left(64.056^{\circ} \mathrm{N}, 21.283^{\circ} \mathrm{W}\right)$. This region contains a network of small streams and springs that vary significantly in ambient temperature $\left(\sim 6-100{ }^{\circ} \mathrm{C}\right)$. These large temperature differences result from indirect, local geothermal heating of soils and bedrock, and streams consequently show little variation in solute chemistry, which is similar to many pristine subarctic streams. Importantly, indirect geothermal heating does not produce unusual solute chemistry often associated with volcanic regions (Friberg et al., 2009; O'Gorman et al., 2012). The dominant geology is young basalt (Árnason et al., 1969). Streams in the study area exhibit low dissolved molar N:P ratios $(<3)$, with primary production believed to be primarily, but not exclusively, N-limited (Friberg et al., 2009; Gundmundsdottir et al., 2011). 


\section{Experimental design}

We conducted a controlled and replicated warming experiment using a relatively cold $\left(6.7 \pm 1.7{ }^{\circ} \mathrm{C}\right.$, mean \pm SD during MayAug 2013) unnamed tributary of the Hengladalsá River. We manipulated water temperature in our treatments (Table 1) using gravity-fed heat-exchanger systems (HEX) placed in geothermally heated springs (see Welter et al., 2015 for full design description). The HEX supplied water of varying temperatures $\left(7.5-23.6{ }^{\circ} \mathrm{C}\right)$ to 15 open-topped U-shaped PVC channels (length: $3 \mathrm{~m}$, width: $25.4 \mathrm{~mm}$, height: $40 \mathrm{~mm}$ ) arrayed in parallel facing magnetic south (Fig. S2). Our temperature treatments were chosen to complement the temperature range ( $\sim 6-$ $30{ }^{\circ} \mathrm{C}$ ) of natural streams in the Hengill region (i.e. streams without extremophilic organisms). Channels were divided into three blocks with five channels per block. Temperature treatments were randomly assigned to channels within blocks ( $n=5$ treatments, $n=3$ replicates). Water temperature at the head of each channel was logged (HOBO Pendant, Onset Computer Corp., MA, USA) at 15-min intervals. Mean channel discharge, velocity, and depth were standardized at $0.03 \pm 0.004 \mathrm{~L} / \mathrm{s}, \quad 0.24 \pm 0.05 \mathrm{~m} / \mathrm{s}, \quad$ and $\quad 6.1 \pm 1.7 \mathrm{~mm}$ (mean $\pm 1 \mathrm{SD}$ ) across channels respectively. Preleached basalt tiles ( $25 \times 25 \mathrm{~mm}$; Deko Tile, CA, USA; $n \approx 110$ per channel) were deployed on 20 May 2013, and biofilm communities were allowed to colonize tiles naturally. All tiles were destructively sampled without replacement throughout the experiment.

\section{Ecosystem metabolism}

We assessed ecosystem metabolism on tiles three times (after 30,42 , and 58 days) by measuring oxygen changes in $0.27 \mathrm{~L}$ clear, recirculating chambers (Welter et al., 2015). On each date, four tiles were randomly selected from each treatment (total surface area $24 \mathrm{~cm}^{2}$ ) and placed in chambers containing sieved $(250-\mu \mathrm{m}) \mathrm{HEX}$ source water from each treatment. We measured net ecosystem production (NEP) under ambient light conditions and ecosystem respiration (ER) in complete darkness, maintaining consistent treatment temperatures. Dissolved oxygen (DO) and internal chamber temperatures were recorded at 1-min intervals (YSI, Pro-ODO, OH, USA) during the $\sim 1.5 \mathrm{~h}$ incubations. NEP and ER (mg DO m $\left.{ }^{-2} \mathrm{~h}^{-1}\right)$ were calculated as:

$$
(\mathrm{NEP}, \mathrm{ER})=\left(\Delta \mathrm{O}_{2}-\mathrm{WC}\right) \times(\mathrm{V} / \mathrm{S})
$$

where $\Delta \mathrm{O}_{2}$ is the change in $\mathrm{DO}$ concentration per unit time (mg DO $\mathrm{L}^{-1} \mathrm{~h}^{-1}$ ), $V$ is chamber volume (L), $S$ is the active surface area of the tiles $\left(\mathrm{m}^{2}\right)$, and WC is the water column metabolic rate (mg DO L ${ }^{-1} \mathrm{~h}^{-1}$ ), which was minimal. Gross primary production (GPP) was calculated as GPP $=\mathrm{NEP}+\mathrm{ER}($ Bott, 2006).

\section{Nutrient uptake}

We measured $\mathrm{NH}_{4}-\mathrm{N}$ and SRP uptake in the recirculating chambers on three dates $\left(\mathrm{NH}_{4}^{+}-\mathrm{N}\right.$ : 31, 44, and 65 days; SRP: 32, 43 , and 66 days) on different tiles (total surface area $24 \mathrm{~cm}^{2}$ ). Ammonium-N and orthophosphate-P spikes (as $\mathrm{NH}_{4} \mathrm{Cl}$ and $\mathrm{Na}_{2} \mathrm{HPO}_{4}$ ) were added to a target concentration of $\sim 50 \mu \mathrm{g} / \mathrm{L}$ above ambient ( $\sim 5$-fold $\mathrm{N}$ and $\sim 3$-fold $\mathrm{P}$ increase) at the beginning of the incubations. This level of nutrient addition was chosen to reduce the risk of nutrient-limiting conditions during incubations. We believe this approach captured values that are largely representative of natural uptake rates; however, an addition of surplus bioavailable nutrients may have resulted in slightly overestimated uptake rates (O'Brien \& Dodds, 2008). Triplicate water samples were collected at the beginning and end of incubations (typically $1.5 \mathrm{~h}$ ), filtered immediately through $0.45-\mu \mathrm{m}$ glass-fiber filters and stored $<5 \mathrm{~h}$ in the dark until frozen. We analyzed samples with colorimetric (SRP; APHA, 2012) or fluorometric techniques $\left(\mathrm{NH}_{4}^{+}-\mathrm{N}\right.$; Holmes et al., 1999; Taylor et al., 2007). Areal uptake $\left(\mu \mathrm{g} \mathrm{m}^{-2} \mathrm{~h}^{-1}\right)$ was calculated as the difference between nutrient mass ( $\mu \mathrm{g} \mathrm{L}^{-1} \times$ chamber volume [L]) pre- and postincubation, divided by the surface area $\left(\mathrm{m}^{2}\right)$ of tiles and incubation time (h).

\section{$\mathrm{N}_{2}$-fixation rates}

$\mathrm{N}_{2}$-fixation was measured on three occasions (41, 53, and 69 days) with acetylene reduction assays in the recirculating chambers (Flett et al., 1976; Capone, 1993). Incubation length was $\sim 2 \mathrm{~h}$, with tile selection and handling as outlined above. Gas samples were analyzed with a gas chromatograph (SRI Instruments, 8610, Torrance, CA, USA) within $72 \mathrm{~h}$ of collection, and areal uptake rates of $\mathrm{N}_{2}$-fixation were calculated as the difference between pre- and postincubation gas concentrations divided by tile surface area $\left(\mathrm{m}^{2}\right)$ and length of incubation (h), assuming a 3:1 acetylene: $\mathrm{N}_{2}$ conversion ratio (Capone, 1993; Welter et al., 2015).

\section{Biofilm structure and stoichiometry}

We scrubbed biofilms from tiles immediately following metabolism and $\mathrm{N}_{2}$-fixation incubations, and the resultant slurry

Table 1 Physicochemical characteristics of each temperature treatment

\begin{tabular}{lcrllll}
\hline Treatment & Mean temperature & $\mathrm{NH}_{4}^{+}-\mathrm{N}$ & $\mathrm{NO}_{3}-\mathrm{N}$ & SRP & DO & Specific conductivity \\
\hline $\mathrm{A}$ & $7.5(2.3)$ & $11.6(7.1)^{\mathrm{a}}$ & $52.2(44.2)^{\mathrm{a}}$ & $16.6(7.8)^{\mathrm{a}}$ & $11.5(0.4)^{\mathrm{a}}$ & $68.8(2.6)^{\mathrm{a}}$ \\
$\mathrm{B}$ & $11.2(2.2)$ & $7.0(4.7)^{\mathrm{a}}$ & $37.0(31.3)^{\mathrm{a}}$ & $19.0(6.8)^{\mathrm{a}}$ & $11.5(0.4)^{\mathrm{a}}$ & $67.7(2.8)^{\mathrm{ab}}$ \\
$\mathrm{C}$ & $15.5(2.3)$ & $11.5(5.5)^{\mathrm{a}}$ & $46.0(40.6)^{\mathrm{a}}$ & $15.3(4.0)^{\mathrm{a}}$ & $11.4(0.5)^{\mathrm{a}}$ & $67.4(2.7)^{\mathrm{ab}}$ \\
$\mathrm{D}$ & $19.0(2.2)$ & $7.5(5.1)^{\mathrm{a}}$ & $45.2(44.3)^{\mathrm{a}}$ & $18.6(8.7)^{\mathrm{a}}$ & $10.7(0.5)^{\mathrm{b}}$ & $67.4(3.0)^{\mathrm{c}}$ \\
$\mathrm{E}$ & $23.6(2.4)$ & $11.8(7.3)^{\mathrm{a}}$ & $41.2(43.2)^{\mathrm{a}}$ & $15.4(7.3)^{\mathrm{a}}$ & $10.0(0.4)^{\mathrm{b}}$ & $67.6(2.8)^{\mathrm{d}}$ \\
\hline
\end{tabular}

Mean treatment temperature $\left({ }^{\circ} \mathrm{C} \pm 1 \mathrm{SD}\right)$, ammonium-N ( $\left.\mu \mathrm{g} \mathrm{N} / \mathrm{L} \pm 1 \mathrm{SD}\right)$, nitrate $(\mu \mathrm{g} \mathrm{N} / \mathrm{L} \pm 1 \mathrm{SD})$, soluble reactive phosphorus (SRP; $\mu \mathrm{g}$ P/L $\pm 1 \mathrm{SD}$ ), dissolved oxygen (DO; $\mathrm{mg} \mathrm{O}_{2} / \mathrm{L} \pm 1 \mathrm{SD}$ ), and specific conductivity ( $\mu \mathrm{S} \pm 1 \mathrm{SD}$ ). Superscript letters indicate statistically similar groups. 
was homogenized, subsampled and filtered onto glass-fiber filters to estimate ash-free dry mass (AFDM), C, N, and P content (Whatman ${ }^{\mathrm{TM}} \mathrm{GF} / \mathrm{F}$ filters), and chlorophyll $a$ (chl $a$; Andwin Scientific A/E filters). Individual and separate filters were used for all response metrics, except for $\mathrm{C}$ and $\mathrm{N}$, which were processed on the same filter. We only sampled nutrient incubation tiles for AFDM. Chlorophyll a samples were collected in amber bottles and kept cool during transport to our laboratory, where they were processed immediately. We used a $\sim 24 \mathrm{~h}$ acetone extraction and measured chl $a$ with a handheld fluorometer (Turner Designs, Aquafluor, CA, USA). AFDM, C, N, and P filters were dried at $55^{\circ} \mathrm{C}$ for $\geq 72 \mathrm{~h}$. AFDM reflects the difference between filter dry weight and ash weight after $2 \mathrm{~h}$ at $500{ }^{\circ} \mathrm{C}$. We determined $\mathrm{C}$ and $\mathrm{N}$ content with an elemental analyzer (Costech Analytical Technologies, Inc., CA, USA) and P content with colorimetric techniques (American Public Health Association (APHA), 2012). Community composition subsamples were preserved in $\sim 5 \%$ glutaraldehyde, concentrated via centrifugation, and examined at $400 \times$ magnification in a $0.1-\mathrm{mL}$ Palmer counting chamber (Lowe \& LaLiberte, 2006). Biovolume of distinct autotroph taxa (largely identified to genus) was calculated using established taxon-specific geometries (Sun \& Liu, 2003).

\section{Nutrient demand and use efficiency}

We calculated a predicted net nutrient demand of biofilms to assess whether our estimates of predicted demand matched our real measurements of $\mathrm{N}$ and $\mathrm{P}$ uptake rate. Predicted net nutrient demand was calculated as the product of measured $\operatorname{NEP}\left(\right.$ moles $\mathrm{C} \mathrm{m}^{-2} \mathrm{~h}^{-1}$ ) and biofilm nutrient: $\mathrm{C}$ ratio. NEP values were converted to units of $\mathrm{C}$ assuming a photosynthetic quotient of 1.2 (Bott, 2006). We chose NEP over the more commonly used NPP (Pastor \& Bridgham, 1999) to avoid assumptions about the fraction of GPP respired by autotrophs.

To assess how temperature influenced the coupling of $\mathrm{C}$ and nutrient fluxes, we calculated biofilm nutrient UEs for $\mathrm{N}$ and $\mathrm{P}$ across the thermal gradient. We present two measures of nutrient UE. First, we present biofilm C:N and C:P ratios, which can reflect the net nutrient UE of the community if we assume that (i) biofilms are dominated by actively growing cells and (ii) biofilm stoichiometry reflects net nutrient requirements over ecologically important time scales. Second, we calculated biofilm nutrient UEs using our measured fluxes of $\mathrm{C}$ and nutrients into the biofilm. Here, nutrient UE was calculated as mean NEP (moles $\mathrm{C} \mathrm{m}^{-2} \mathrm{~h}^{-1}$ ) per unit nutrient acquired (moles $\mathrm{N}$ or $\mathrm{P} \mathrm{m}^{-2} \mathrm{~h}^{-1}$; Pastor \& Bridgham, 1999). $\mathrm{P}$ use efficiency (P-UE) was calculated with SRP uptake rate, while nitrogen use efficiency (N-UE) was calculated using $\mathrm{NH}_{4}^{+}-\mathrm{N}$ uptake rates only $\left(\mathrm{N}-\mathrm{UE}_{\mathrm{U}}\right)$ or with combined $\mathrm{N}_{2}$-fixation and $\mathrm{NH}_{4}^{+}-\mathrm{N}$ uptake rates $\left(\mathrm{N}-\mathrm{UE}_{\mathrm{UF}}\right)$.

\section{Data analysis}

We analyzed data with repeated measures mixed-effects models fit with the 'lme' function in the R package 'nlme'. Correlation coefficients were generated with the 'r.squaredGLMM' function in the 'MUMIN' package (R Core Team, 2013). We fit an initial 'full' model that included temperature, day, and a temperature $\times$ day interaction as fixed effects, and channel identity as a random effect. We used model selection techniques (Akaike Information Criterion; AIC; Bozdogan, 1987) to determine the most appropriate model given the data. Occasionally, residual plots suggested nonlinear responses to temperature. For these metrics we used repeated measures analysis of variance (RMANOVA) and AIC value model selection (Bozdogan, 1987; Cottingham et al., 2005). This is a more conservative approach for addressing potential threshold temperature effects, thus avoiding assumptions about the shape of nonlinear models. Least-squares regressions were fit to individual sample periods with the ' $1 \mathrm{~m}$ ' function in the $\mathrm{R}$ package 'stats' when limited data points restricted use of mixed-effects models (R Core Team 2013). Individual rate measurements were discarded when below our detection thresholds. Response metrics were $\log _{e}(x)$-transformed to meet model assumptions of normality when appropriate, and all analyses were conducted with an alpha of 0.05 .

\section{Results}

\section{Temperature manipulation}

The ambient temperature treatment had a temperature regime that was largely similar - in both temperature and diel pattern - to the source stream. The other four treatments were on average $3.7,8.0,11.5$, and $16.1^{\circ} \mathrm{C}$ above ambient, while also exhibiting diel temperature patterns similar to the source stream (Table 1; Fig. S1). Dissolved nutrient concentrations at the upstream end of the channels did not differ among treatments (RMANOVA: SRP, $F_{5,20}=0.85, P=0.53 ; \mathrm{NH}_{4}^{+}-\mathrm{N}, F_{5,20}=2.06$, $\left.P=0.113 ; \mathrm{NO}_{3}-\mathrm{N}, F_{5,20}=0.67, P=0.65\right)$. Both specific conductivity and dissolved oxygen (DO) concentration decreased slightly at higher temperatures (Table 1; rmANOVA: specific conductivity, $F_{5,30}=8.90$, $P<0.001 ;$ DO, $\left.F_{5,30}=86.24, P<0.001\right)$.

\section{Biomass and community structure}

Warming had a strong positive effect on biomass and chl $a$ of stream biofilms. Biomass (as AFDM) varied 2.8,20-, and 24-fold across the temperature treatments at 30, 42, and 58 days, respectively (Fig. 1a, Table 2), while areal chl $a$ concentrations varied 50-, 231-, and 174-fold at 30, 42 and 58 days respectively (Fig. 1b, Table 2). Biofilm community composition was dominated by $\mathrm{N}_{2}$-fixing cyanobacteria (largely Nostoc and Anabaena spp.) in all temperature treatments (Table 3). This functional group comprised $>91 \%$ of community biovolume regardless of temperature. The remaining functional groups included green and yellow-green algae $(2.8 \pm 8.0 \%$, mean $\pm \mathrm{SD})$, diatoms $(1.8 \pm 1.5 \%)$, and diatoms with cyanobacterial endosymbionts (largely Epithemia and Rhopalodia spp.; $0.5 \pm 1.4$; Table 3). 

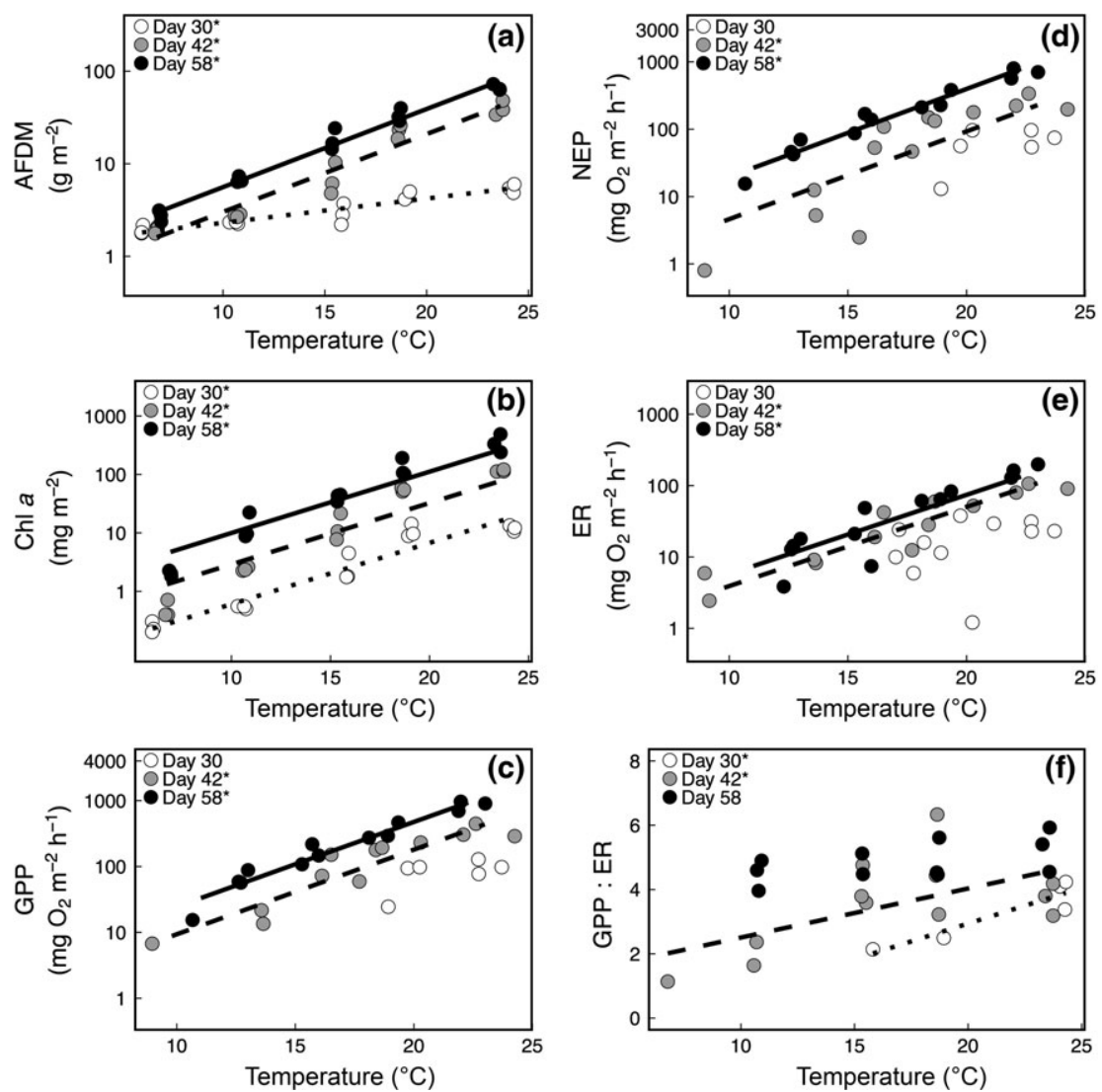

Fig. 1 Ash-free dry mass (AFDM); (a), chlorophyll $a$ (chl $a$; b), gross primary production (GPP); (c), net ecosystem production (NEP); (d), ecosystem respiration (ER); (e), and the instantaneous (not diurnally integrated) ratio of GPP to ER (f) increased across the temperature gradient. Scale of $y$-axes is $\log _{\mathrm{e}}$-linear, and asterisks and model fit are displayed when significant $(\alpha \leq 0.05)$. Dotted, dashed, and solid trend lines represent the first, second, and third sample periods respectively.

\section{Metabolism}

Rates of NEP, GPP, and ER exhibited a positive exponential relationship with temperature, excepting the first sampling period when limited data suggested similar trends, but precluded characterization of the relationship with temperature. On days 42 and 58, GPP varied 51- and 55-fold across the treatments, NEP varied 317- and 44-fold, and ER varied 22- and 42-fold respectively (Fig. 1c, d, e; Table 2). On day 30, GPP, NEP and ER did not vary between the two warmest treatments in which we were able to measure these fluxes. During daylight hours the channels were strongly autotrophic (GPP: $\mathrm{ER}=4.0 \pm 1.2$, mean $\pm \mathrm{SD}$ ) and during the first two sampling periods, the degree of autotrophy increased with temperature (i.e. 2- and 5.5-fold over the temperature range; least-squares regression; 30 days; $r^{2}=0.80, P=0.024$, intercept $=-1.4 \pm 1.1$, $\beta=0.22 \pm 0.05 ; 42$ days; $r^{2}=0.29, \quad P=0.039$, intercept $=0.98 \pm 1.1, \quad \beta=0.15 \pm 0.06, \quad$ estimate $\pm \mathrm{SE}$; Fig. 1f).

\section{Biofilm stoichiometry}

Temperature had inconsistent effects on biofilm $\mathrm{C}$ and $\mathrm{N}$ content, except for a single sampling date (day 58) where significant increases with temperature were observed (Fig. 2a, b). Warming led to increased C (1.3fold; from 13.9 to $25 \%$ ) and $\mathrm{N}$ content (1.4-fold; from 1.6 to $2.8 \%$ ) at 58 days (Fig. 2a, b; Table 4). On this date, C and $\mathrm{N}$ content was highest in the two middle temperature treatments $\left(15.5\right.$ and $\left.19^{\circ} \mathrm{C}\right)$, relative to the coldest $\left(7.5\right.$ and $\left.11.2{ }^{\circ} \mathrm{C}\right)$ and warmest $\left(23.6^{\circ} \mathrm{C}\right)$ treatments (Table S1). Biofilm P content, which varied 2.0- to 2.5fold across the treatments, exhibited a positive-saturating relationship with temperature (Fig. 2c; Table 4; Table S1). Biofilm C:N ratios did not differ significantly among temperature treatments, with the exception of a small, but significant decrease with temperature on a single date (30 days; Fig. 2d; Table 4; Table S1). In contrast, warming had a significant negative effect on biofilm C:P (30 and 58 days) and N:P ratios (30, 42, and 58 days). These changes were largely driven by relatively high C:P and N:P ratios in the coldest (i.e. ambi- 
Table 2 Results of mixed-effects models for $\log _{e}(x)$-transformed ash-free dry mass (AFDM, $\left.\mathrm{g} \mathrm{m}^{-2}\right)$, chlorophyll $a\left(\mathrm{Chl} a\right.$, $\mathrm{mg} \mathrm{m}^{-2}$ ), gross primary productivity (GPP, $\mathrm{mg} \mathrm{O}_{2} \mathrm{~m}^{-2} \mathrm{~h}^{-1}$ ), net ecosystem productivity (NEP, $\mathrm{mg} \mathrm{O}_{2} \mathrm{~m}^{-2} \mathrm{~h}^{-1}$ ), ecosystem respiration (ER, $\left.\mathrm{mg} \mathrm{O}_{2} \mathrm{~m}^{-2} \mathrm{~h}^{-1}\right)$, ammonium $\left(\mathrm{NH}_{4}^{+}-\mathrm{N}\right)$ uptake $\left(\mu \mathrm{g} \mathrm{N} \mathrm{m}^{-2} \mathrm{~h}^{-1}\right)$, and soluble reactive phosphorus (SRP) uptake $\left(\mu \mathrm{g} \mathrm{P} \mathrm{m}^{-2} \mathrm{~h}^{-1}\right)$.

\begin{tabular}{|c|c|c|c|c|c|c|c|}
\hline \multirow{2}{*}{$\begin{array}{l}\text { Fixed } \\
\text { effects }\end{array}$} & \multirow{2}{*}{$\frac{\mathrm{AFDM}}{\beta(\mathrm{SE})}$} & \multirow{2}{*}{$\frac{\mathrm{Chl} a}{\beta(\mathrm{SE})}$} & \multirow{2}{*}{$\frac{\mathrm{GPP}}{\beta(\mathrm{SE})}$} & \multirow{2}{*}{$\frac{\mathrm{NEP}}{\beta(\mathrm{SE})}$} & \multirow{2}{*}{$\frac{\mathrm{ER}}{\beta(\mathrm{SE})}$} & \multirow{2}{*}{$\begin{array}{l}\mathrm{NH}_{4}^{+}-\mathrm{N} \\
\text { uptake }\end{array}$} & \multirow{2}{*}{$\begin{array}{l}\begin{array}{l}\text { SRP } \\
\text { uptake }\end{array} \\
\beta(\mathrm{SE})\end{array}$} \\
\hline & & & & & & & \\
\hline Intercept & $0.22(0.10)^{*}$ & $-2.91(0.23)^{* * *}$ & $-2.01(0.46)^{* * *}$ & $-2.61(0.44)^{* * *}$ & $-2.45(0.37)^{* * *}$ & $5.95(0.23)^{* * *}$ & $5.51(0.34)^{* * *}$ \\
\hline Temp. & $0.06(0.01)^{* * *}$ & $0.24(0.01)^{* * *}$ & $0.29(0.01)^{* * *}$ & $0.30(0.01)^{* * *}$ & $0.25(0.01)^{* * *}$ & $0.07(0.001)^{* * *}$ & $0.07(0.01)^{* * *}$ \\
\hline Day 42 & $-1.06(0.13)^{* * *}$ & $1.56(0.16)^{* * *}$ & $1.32(0.22)^{* * *}$ & $1.14(0.26)^{* * *}$ & $1.26(0.35)^{* *}$ & $0.67(0.19)^{* *}$ & $-0.39(0.36)$ \\
\hline Day 58 & $-0.45(0.14)^{* *}$ & $2.80(0.17)^{* * *}$ & $2.29(0.30)^{* * *}$ & $2.59(0.31)^{* * *}$ & $1.64(0.34)^{* * *}$ & $0.61(0.18)^{* *}$ & $-0.09(0.29)$ \\
\hline $\begin{array}{l}\text { Temp.* } \\
\text { Day } 42\end{array}$ & $0.13(0.01)^{* * *}$ & - & - & - & - & - & - \\
\hline $\begin{array}{l}\text { Temp.* } \\
\text { Day } 58\end{array}$ & $0.13(0.01)^{* * *}$ & - & - & - & - & - & - \\
\hline $\begin{array}{l}\text { Random } \\
\text { effects }\end{array}$ & SD & SD & SD & SD & SD & SD & SD \\
\hline $\begin{array}{l}\text { Channel } \\
\text { (intercept) }\end{array}$ & 0.14 & 0.43 & 0.70 & 0.79 & 0.97 & 0.63 & 0.94 \\
\hline $\begin{array}{l}\text { Day } 42 \\
\text { (slope) }\end{array}$ & 0.16 & 0.60 & 0.53 & 0.30 & 1.22 & 0.67 & 1.28 \\
\hline $\begin{array}{l}\text { Day } 58 \\
\text { (slope) }\end{array}$ & 0.19 & 0.64 & 0.87 & 0.87 & 1.17 & 0.56 & 0.94 \\
\hline Residuals & 0.05 & 0.17 & 0.14 & 0.19 & 0.15 & 0.16 & 0.14 \\
\hline$R_{\mathrm{GLMM}(\mathrm{m})}^{2}$ & 0.96 & 0.91 & 0.85 & 0.73 & 0.68 & 0.57 & 0.29 \\
\hline$R_{\mathrm{GLMM}(\mathrm{c})}^{2}$ & 0.99 & 0.99 & 0.98 & 0.98 & 0.98 & 0.94 & 0.97 \\
\hline
\end{tabular}

We initially fit a 'full' model that included temperature, day, and a temperature $\times$ day interaction as fixed effects and channel identity as an additional random effect. We used model selection techniques to select the most appropriate model (Akaike Information Criterion; AIC). The marginal $R^{2}$ (GLMM[m]; fixed effects only) and the conditional $R^{2}$ (GLMM[c]; fixed and random effects) represent the proportion variance explained by each model. Day is approximate, as response variables were measured on separate, but generally consecutive days. $\mathrm{SE}=$ standard error; $\mathrm{SD}=$ standard deviation; ${ }^{*} P<0.05,{ }^{* *} P<0.01,{ }^{*} P<0.001$.

Table 3 Functional group composition of biofilm communities (mean $\% \pm 1$ SD) by biovolume and averaged across time periods

\begin{tabular}{lllll}
\hline Mean temperature & Cyanobacteria & Diatoms & $\mathrm{N}_{2}$-fixing diatoms & Green and yellow-green algae \\
\hline 7.5 & $98.2(2.3)$ & $1.6(2.3)$ & $0.02(0.07)$ & $0.04(0.08)$ \\
11.2 & $97.9(1.7)$ & $1.1(0.4)$ & 0 & $0.8(1.6)$ \\
15.5 & $98.5(1.0)$ & $1.2(1.0)$ & $0.02(0.03)$ & $0.2(0.3)$ \\
19.0 & $91.7(14.8)$ & $2.4(1.7)$ & $0.7(1.6)$ & $5.1(13.3)$ \\
23.6 & $91.6(8.5)$ & $2.9(1.6)$ & $1.3(2.0)$ & $4.0(7.2)$ \\
\hline
\end{tabular}

ent) temperature treatment (Fig. 2e, f; Table 4; Table S1). Warming above ambient thermal conditions produced a 1.9-fold (C:P) and 1.8-fold (N:P) decrease in elemental ratios; however, no differences were found among treatments above ambient temperature (Fig. 2e, f; Table 4; Table S1).

\section{Nutrient uptake and nitrogen fixation}

Rates of $\mathrm{NH}_{4}^{+}-\mathrm{N}$ uptake and $\mathrm{N}_{2}$-fixation increased across the temperature gradient (Fig. 3a, b; Tables 2 and 4) and, in the warmest treatments, $\mathrm{N}_{2}$-fixation became the dominant flux of $\mathrm{N}$ to the biofilm (Fig. 3c).
Temperature had a strong positive effect on $\mathrm{N}_{2}$-fixation rates, which varied 22-, 121-, and 64-fold on days 41, 53, and 69 (Fig. 3b; Table 4). $\mathrm{NH}_{4}^{+}-\mathrm{N}$ uptake rates were positively and exponentially related to temperature, but the increase across the thermal gradient was much shallower than that of $\mathrm{N}_{2}$-fixation, increasing only 6.8-, 3.2-, and 2.8-fold on days 31, 44, and 65 (Fig. 3a; Table 2). Thus, in the cold treatments, $\mathrm{NH}_{4}^{+}-\mathrm{N}$ uptake rates were greater than $\mathrm{N}_{2}$-fixation rates, especially early in the experiment. In the warmest treatments, $\mathrm{N}_{2}$-fixation rates were over two times higher than $\mathrm{NH}_{4}^{+}-\mathrm{N}$ uptake rates (Fig. 3c). SRP uptake rates varied 8.6-fold across all treatments and dates, but were only 

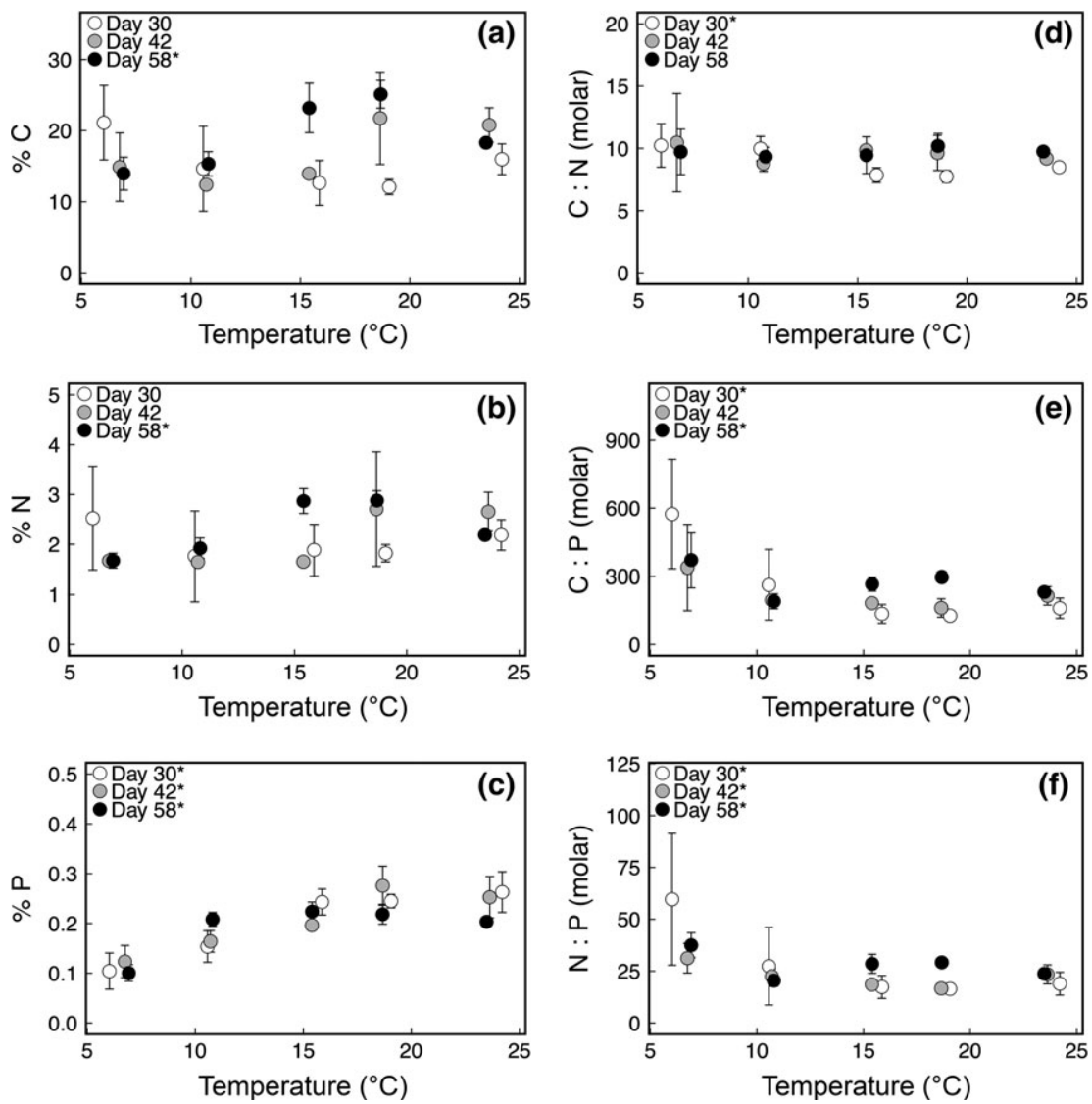

Fig. 2 Carbon $(\mathrm{C}, \mathrm{a})$ and nitrogen $(\mathrm{N}, \mathrm{b})$ content showed mixed nonlinear responses to temperature that were generally positive, while phosphorus $(\mathrm{P}, \mathrm{c})$ content clearly increased with temperature. $\mathrm{C}: \mathrm{N}(\mathrm{d})$ was temperature-invariant, whereas C:P (e) and N:P (f) ratios decreased at temperatures above ambient. Asterisks displayed in the legend indicate significant relationships $(\alpha=0.05)$, error bars are \pm 1 SD.

Table 4 Repeated measures analysis of variance was used in instances where residual plots suggested evidence of a nonlinear temperature response

\begin{tabular}{|c|c|c|c|c|c|c|c|}
\hline & $\begin{array}{l}\log _{e} N_{2} \text {-fixation } \\
\left(\mu \mathrm{g} \mathrm{m}^{-2} \mathrm{~h}^{-1}\right)\end{array}$ & $\mathrm{C}(\%)$ & $\mathrm{N}(\%)$ & $\mathrm{P}(\%)$ & $\begin{array}{l}\mathrm{C}: \mathrm{N} \\
\text { (molar ratio) }\end{array}$ & $\begin{array}{l}\mathrm{C}: \mathrm{P} \\
\text { (molar ratio) }\end{array}$ & $\begin{array}{l}\mathrm{N}: \mathrm{P} \\
\text { (molar ratio) }\end{array}$ \\
\hline Intercept & - & - & - & - & - & - & - \\
\hline Degrees of freedom & 1,28 & 1,20 & 1,20 & 1,28 & 1,20 & 1,20 & 1,20 \\
\hline$F$-statistic & $14513.7^{* * *}$ & $2857.9^{* * *}$ & $2698.5^{* * *}$ & $2718.6^{* * *}$ & $7096.3^{* * *}$ & $2203.6^{* * *}$ & $1957.4^{* * *}$ \\
\hline Treatment (temp.) & - & - & - & - & - & - & - \\
\hline Degrees of freedom & 4,10 & 4,10 & 4,10 & 4,10 & 4,10 & 4,10 & 4,10 \\
\hline F-statistic & $145.6^{* * *}$ & $27.6^{* * *}$ & $24.15^{* * *}$ & $40.5^{* * *}$ & $4.1^{*}$ & $15.6^{* * *}$ & $9.9^{* *}$ \\
\hline Day & - & - & - & - & - & - & - \\
\hline Degrees of freedom & 2,28 & 2,20 & 2,20 & 2,28 & 2,20 & 2,20 & 2,20 \\
\hline F-statistic & $11.8^{* * *}$ & $6.7^{* *}$ & 2.4 & 0.8 & 2.0 & 1.2 & $9.3^{* *}$ \\
\hline Treatment (temp.) * Day & - & - & - & - & - & - & - \\
\hline Degrees of freedom & - & 8,20 & 8,20 & - & 8,20 & 8,20 & 8,20 \\
\hline F-statistic & - & $6.6^{* * *}$ & $3.7^{* *}$ & - & 1.2 & $2.9^{*}$ & $3.1^{*}$ \\
\hline
\end{tabular}

A full model was fit for each variable with the covariates temperature, day, and a temperature $\times$ day interaction. Model selection methods (Akaike Information Criteria; AIC) were used to determine the final model. Carbon (C) content, nitrogen (N) content, C:N, C:phosphorus (P), and N:P were all fit with the full model, and $\mathrm{N}_{2}$-fixation and P content were fit with a reduced model containing only the terms temperature and day. ${ }^{*} P<0.05,{ }^{* *} P<0.01,{ }^{* * *} P<0.001$. 

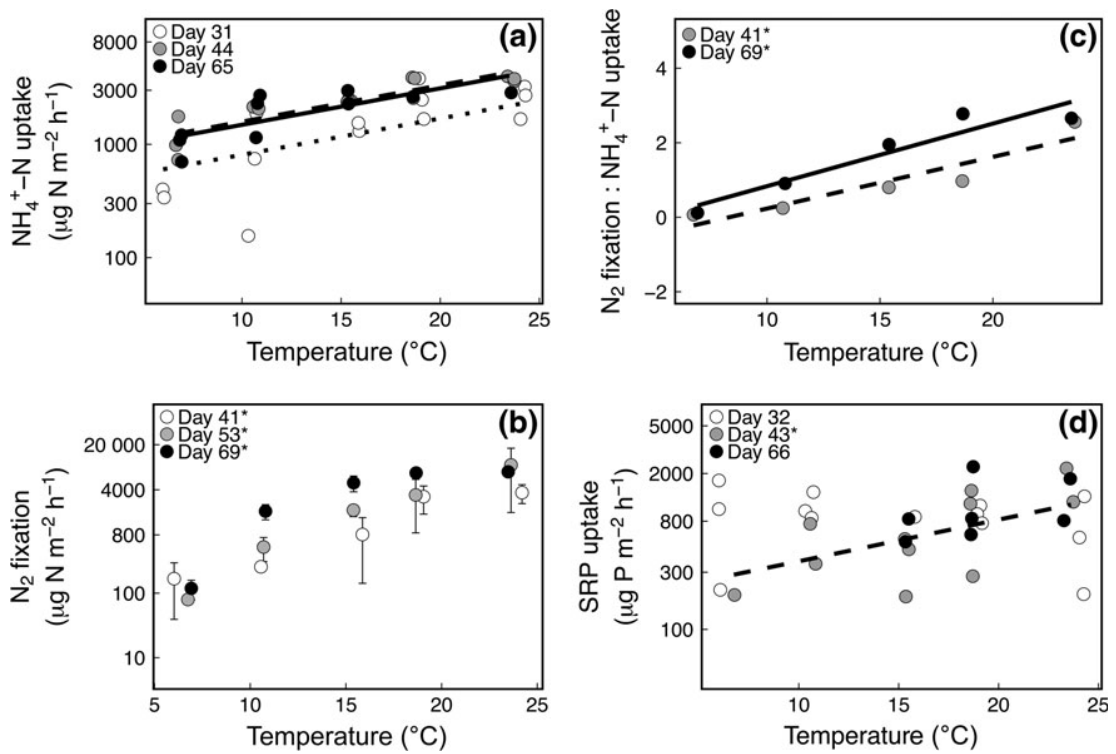

Fig. 3 Rates of nitrogen uptake $\left(\mathrm{NH}_{4}{ }^{+}-\mathrm{N}\right)$; (a) and $\mathrm{N}_{2}$-fixation (b) increased across the temperature gradient. At warmer temperatures, $\mathrm{N}_{2}$-fixation supplied the majority of total $\mathrm{N}$ (c) flux to the system. Phosphorus (P) uptake (as soluble reactive phosphorus; SRP) increased with temperature on a single date and was highly variable $(\mathrm{d})$. Model fit and asterisks displayed when significant $(\alpha=0.05)$. Scale of $y$-axes in panels a,b,d are $\log _{\mathrm{e}}$-linear, and dotted, dashed, and solid lines represent the first, second, and third sample periods respectively. Ratios of $\mathrm{N}_{2}$-fixation: $\mathrm{N}$ uptake utilize data measured on separate dates under similar conditions. Error bars are \pm 1 SD.

weakly related to temperature on one sampling date (Fig. 3d; Table 2).

\section{Predicted nutrient demand}

We compared our measured $\mathrm{N}$ (i.e. $\mathrm{NH}_{4}^{+}-\mathrm{N}$ uptake and $\mathrm{N}_{2}$-fixation) and P (i.e. SRP uptake) assimilation rates to predicted nutrient demand based on GPP and biofilm stoichiometry (Fig. 4). SRP uptake was positively related $\left(r^{2}=0.34, P=0.003\right)$ to predicted $\mathrm{P}$ demand, and the $95 \%$ confidence interval for this relationship overlapped the 1:1 line for most of the range in predicted P demand; however, this was not true at the lower end of the predicted values where the majority of the data points were located (Fig. 4a). $\mathrm{NH}_{4}^{+}-\mathrm{N}$ uptake was similarly related to predicted $\mathrm{NH}_{4}^{+}-\mathrm{N}$ demand $\left(r^{2}=0.36\right.$, $P=0.032$; Fig. $4 \mathrm{~b}$ ), yet results from treatments warmer than ambient temperatures fell far below the 1:1 line, suggesting a decoupling between GPP and $\mathrm{NH}_{4}^{+}-\mathrm{N}$ uptake with warming. Including $\mathrm{N}_{2}$-fixation in our measurement of total $\mathrm{N}$ assimilation (on the $y$-axis) resulted in a much greater correspondence between predicted and measured $\mathrm{N}$ assimilation (Fig. 4c). Nonetheless, we still tended to over-predict $\mathrm{N}$ assimilation at cold temperatures and under-predict $\mathrm{N}$ assimilation at warm temperatures (Fig. 4c).

\section{Nutrient use efficiency}

We examined nutrient use efficiency (UE) from two perspectives: (i) bulk stoichiometry, which represents net accumulation of elements, and (ii) relative fluxes of $\mathrm{C}$ and nutrients into biofilms. C:P stoichiometry varied little across the thermal gradient, suggesting that $\mathrm{P}$ use efficiency (P-UE) was unaffected by temperature. However, estimates of P-UE based on the fluxes of $\mathrm{C}$ and $\mathrm{P}$ to the biofilm suggested that warming had a positive effect on P-UE on day 42, the single date containing sufficient data (a 37-fold increase; $r^{2}=0.70, P=0.046$, intercept $=0.08 \pm 1.15$, $\beta=0.23 \pm 0.07, \log _{e} \pm \mathrm{SE} ;$ Fig. 5a). The generally invariant response of $\mathrm{C}: \mathrm{N}$ stoichiometry across temperature treatments suggests that $\mathrm{N}$ use efficiency $(\mathrm{N}$ UE) was not influenced by temperature using this metric. In contrast, N-UE estimates based on relative fluxes of $\mathrm{C}$ and $\mathrm{N}$ to biofilms indicated that temperature had a generally positive effect on N-UE. We found that $\mathrm{N}-\mathrm{UE}$ calculated with $\mathrm{NH}_{4}^{+}-\mathrm{N}$ uptake rates only (N-UE $)_{\mathrm{U}}$ increased 56-fold across the temperature gradient (42 days; $r^{2}=0.87, P=0.012$, intercept $=-2.81 \pm 0.85, \quad \beta=0.28 \pm 0.05 ; \quad 58$ days; $r^{2}=0.98, \quad P<0.001, \quad$ intercept $=0.47 \pm 0.14$, $\beta=0.16 \pm 0.009, \quad \log _{e} \pm \mathrm{SE} ; \quad$ Fig. $5 b$ ). N-UE $\mathrm{UF}_{\mathrm{U}}$ (i.e. including both $\mathrm{N}_{2}$-fixation and $\mathrm{NH}_{4}^{+}-\mathrm{N}$ uptake as $\mathrm{N}$ fluxes to the biofilm) also indicated that warming led to increased nutrient UE, but the slopes of these relationships were shallower (average of a 17-fold increase; 42 days: $\quad r^{2}=0.75, \quad P=0.035$, intercept $=-2.36 \pm 0.94, \quad \beta=0.21 \pm 0.05 ; \quad 58$ days: $r^{2}=0.72, \quad P=0.042, \quad$ intercept $=0.68 \pm 0.43$, $\beta=0.09 \pm 0.02, \log _{e} \pm$ SE; Fig. 5c). 

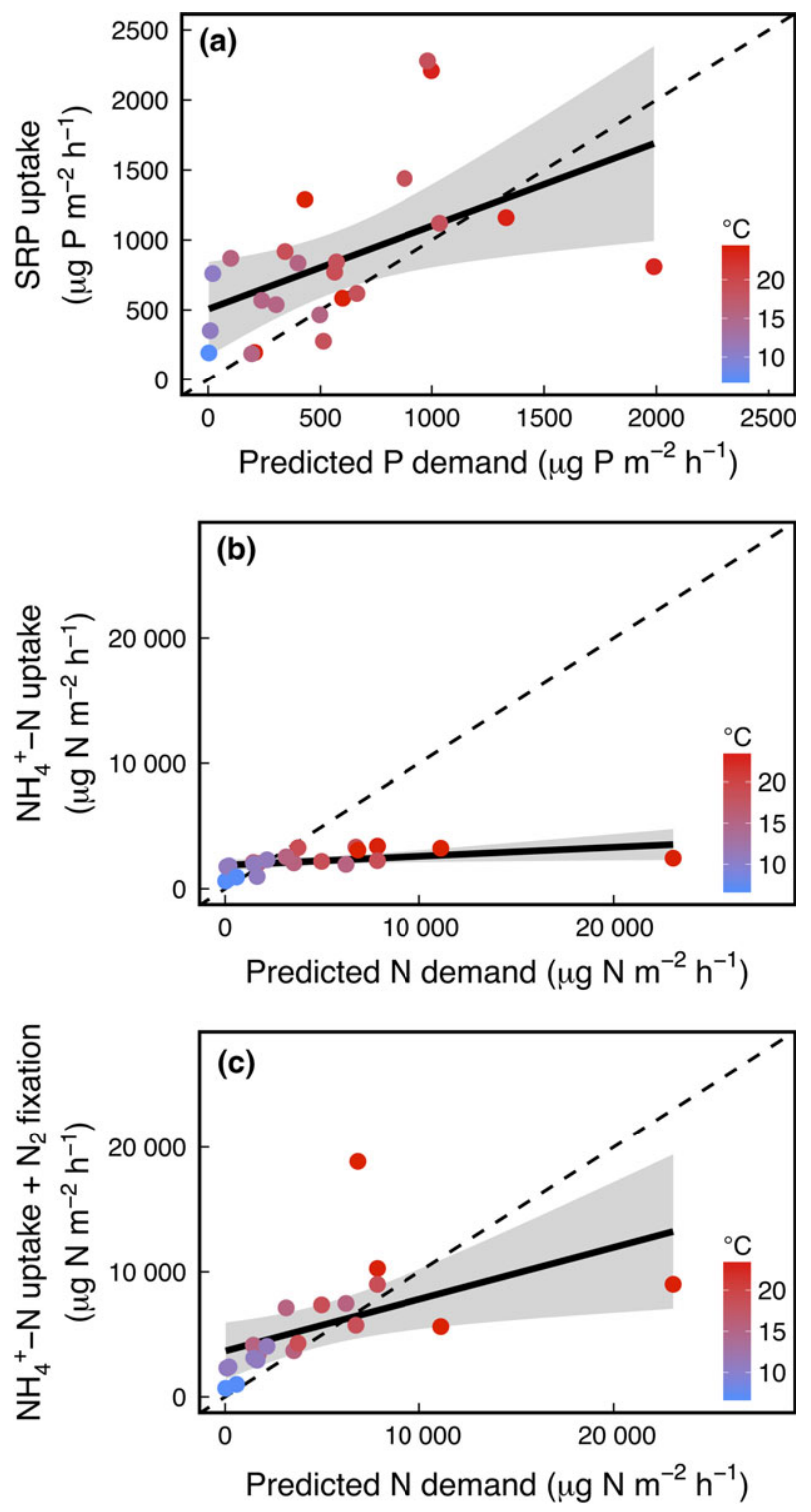

Fig. 4 Phosphorus $(\mathrm{P}, \mathrm{a})$ uptake generally exceeded predicted $\mathrm{P}$ demand, whereas $\mathrm{NH}_{4}{ }^{+}-\mathrm{N}$ uptake (b) only exceeded $\mathrm{N}$ demand at relatively cold temperatures. Incorporating $\mathrm{N}_{2}$-fixation in estimates of total $\mathrm{N}$ acquisition $\left(\mathrm{NH}_{4}{ }^{+}-\mathrm{N}\right.$ uptake $+\mathrm{N}_{2}$-fixation); (c) led to a closer match between total measured and predicted $\mathrm{N}$ demand. Dashed line is 1:1 slope, solid line is least mean squares regression with $95 \%$ confidence intervals in gray.

\section{Discussion}

Our controlled warming experiment revealed strong effects of temperature on the ecosystem function of stream biofilms. Metabolic processes, including gross primary production, ecosystem respiration, and net ecosystem production all increased with warming, despite the relatively low supply of ionic nitrogen known to be limiting at our study site (Friberg et al.,
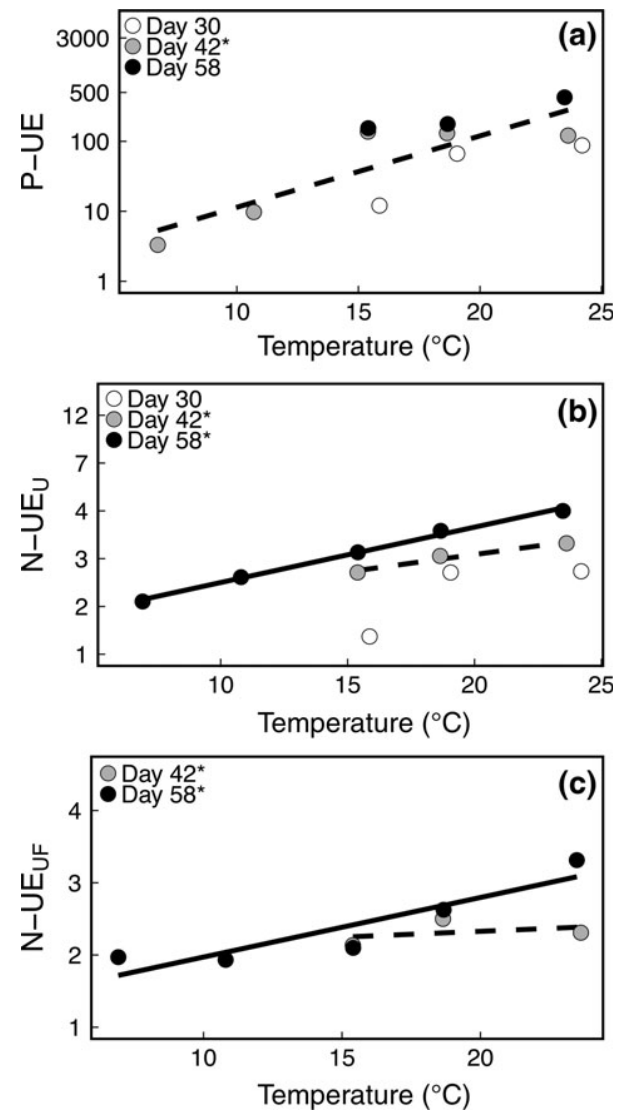

Fig. 5 Phosphorus (P-UE, a), $\mathrm{NH}_{4}{ }^{+}-\mathrm{N}\left(\mathrm{N}-\mathrm{UE}_{\mathrm{U}}, \mathrm{b}\right)$, and $\mathrm{N}_{2}$-fixation $+\mathrm{NH}_{4}{ }^{+}-\mathrm{N}\left(\mathrm{N}-\mathrm{UE}_{\mathrm{UF}}, \mathrm{c}\right)$ use efficiencies increased with increasing temperature when calculated using the relative fluxes of carbon and nutrients (see text). Asterisks and leastsquares regressions indicate significant relationships $(\alpha=0.05)$. Scales of $y$-axes are $\log _{\mathrm{e}}$-linear, and dashed and solid trend lines represent the second and third sample periods respectively. Sampling dates in the legend are approximate because the fluxes used to calculate nutrient use efficiency (NEP, uptake, and $\mathrm{N}_{2}$-fixation) were measured on separate days.

2009). The biomass of autotrophs also increased substantially across the thermal gradient, contrary to recent experiments conducted in lentic environments (YvonDurocher et al., 2010b; Dossena et al., 2012; Shurin et al., 2012; but see Baulch et al., 2005), as well as predictions based on metabolic theory (Allen et al., 2005; Cross et al., 2015). Unexpectedly, biofilm C:nutrient ratios showed a null or negative response (i.e. no change in C: $\mathrm{N}$ and reduced C:P ratios) to warming, suggesting important temperature-induced changes in how nutrients are acquired, stored, and routed. Our results shed new light on the complex ways in which environmental warming may alter the coupling of carbon and nutrient cycles in stream ecosystems.

We found that biofilm C:N ratios remained relatively constant across the temperature treatments, 
despite a significant increase in ecosystem metabolism. These results suggest that both $\mathrm{N}$ and $\mathrm{P}$ assimilation 'kept pace' with $\mathrm{C}$ fixation rates as biomass accumulated with warming. With respect to $\mathrm{N}$, this result was especially surprising given its very low concentration in the source stream. Although ammonium uptake increased significantly with temperature, this flux was grossly insufficient to meet the total predicted $\mathrm{N}$ demand (i.e. based on GPP and biomass stoichiometry; Webster et al., 2003). There are a few possible explanations for this pattern. First, it is possible that increased $\mathrm{N}$ demand at warmer temperatures was met by elevated rates of $\mathrm{N}_{2}$-fixation, bringing a new source of $\mathrm{N}$ to biofilms in the form of $\mathrm{N}_{2}$ gas. Our measured rates of $\mathrm{N}_{2}$-fixation strongly support this hypothesis and suggest that warming can alter the dominant sources and pathways of nitrogen in stream ecosystems (Welter et al., 2015). In the coldest treatment $\mathrm{N}_{2}$-fixation supplied $\sim 9 \%$ of total $\mathrm{N}$ assimilation and $72 \%$ in the warmest treatment, effectively shifting the primary $\mathrm{N}$ source from dissolved ammonium uptake to $\mathrm{N}_{2}$-fixation as the primary $\mathrm{N}$ source. If such a pattern is general (Paerl \& Huisman, 2008), more effort should be dedicated to understanding how warming-induced shifts in the $\mathrm{N}$ cycle may alter the balance of $\mathrm{N}$ uptake and removal (Mulholland et al., 2000), as well as the flux of $\mathrm{N}$ through higher trophic levels (Marcarelli et al., 2008). Moreover, our results highlight the importance of considering functional traits (e.g., $\mathrm{N}_{2}$-fixation) when predicting how coupled biogeochemical cycles will respond to climate change (Webb et al., 2010; Finzi et al., 2011).

Secondly, uptake of nitrate-N may be important for supporting biofilm growth, and we did not explicitly measure this flux. Measurements of whole-stream ammonium vs. nitrate uptake in 9 Hengill streams that vary across a similar temperature range show that ammonium uptake is generally higher than that of nitrate (ratios from $\sim 2: 1$ to 50:1), consistent with other recent studies in these streams (J.M. Hood, unpublished data; Demars et al., 2011; Rasmussen et al., 2011). Despite this, it seems likely that under conditions of higher demand (i.e. warmer temperatures) nitrate-N assimilation would become increasingly important, especially considering the relatively higher energetic cost of $\mathrm{N}_{2}$-fixation (Howarth et al., 1988). This unaccounted source of $\mathrm{N}$ may explain why we progressively over-predict $\mathrm{N}$ assimilation at warmer temperatures.

We also found that biofilms became relatively more P-rich (reduced C:P ratios) in response to warming, in contrast with our original predictions. Although unexpected, this result is not inconsistent with recent work by De Senerpont Domis et al. (2014), which showed little response of algal C:P stoichiometry with warming under P-rich conditions. In our study area, dissolved $\mathrm{P}$ is relatively abundant (i.e. low dissolved $\mathrm{N}: \mathrm{P} ; \mathrm{O}^{\prime}$ Gorman et al., 2012) and this may help explain the lack of a strong SRP uptake response to warming. Additionally, our channels lacked macrophytes which have been shown to strongly influence the relationship between temperature and $\mathrm{P}$ uptake in natural streams (Demars et al., 2011). Indeed, our estimates of predicted P demand from GPP and biofilm stoichiometry suggest that uptake of dissolved $\mathrm{P}$ roughly met, or exceeded, expected P demand at all experimental temperatures.

The microbial assemblage that developed on tiles was dominated by globally ubiquitous cyanobacteria (Paerl \& Huisman, 2008; Lürling et al., 2013). A shift from Nostoc spp. toward Anaebaena and Cylindrospermum spp. was observed across the thermal gradient (J.R. Welter \& P.C. Furey, St. Catherine University, unpublished data). Such a shift in assemblage structure is likely due to thermal optima of individual cyanobacteria taxa, as Anabaena exhibits a relatively high temperature optimum (Kratz \& Myers, 1955; Lüring et al., 2013) and was only observed in the warmest treatment. Changes in species composition were accompanied by increases in $\mathrm{N}_{2}$-fixation rates with warming, which may represent a direct response of the nitrogenase enzyme to increasing temperature (Ceuterick et al., 1978), as well as interspecific differences in $\mathrm{N}_{2}$-fixation potential among taxa. $\mathrm{N}_{2}$-fixers typically have high $\mathrm{P}$ requirements, which may result from the energy-intensive, high adenosine triphosphate (ATP) cost of $\mathrm{N}_{2}$-fixation (Vitousek et al., 2002). Such high $\mathrm{P}$ requirements, together with changes in species composition, may explain the slight reduction in C:P stoichiometry with warming.

Although our prediction that warming would lead to elevated C:nutrient ratios was not supported, we did find a strong positive effect of warming on flux-based nutrient UEs. Such a result could arise from increased nutrient UE of individuals (i.e. physiological changes; Baligar et al., 2001) or community-level shifts toward taxa that use nutrients more efficiently at warm temperatures (Hiremath \& Ewel, 2001), neither of which would necessarily be reflected in the elemental composition of biofilms. Indeed, the metabolic demand for nutrients may not be clearly reflected in biomass if some elements, such as $\mathrm{N}$, are bound to recalcitrant organic molecules and not metabolically active. Moreover, large variation exists in cellular activity within biofilms (Lock et al., 1984) and, if the majority of nutrient uptake takes place on the surface among actively growing cells (Burkholder et al., 1990), we might expect flux-based nutrient UE to increase as bio- 
films develop and thicken. This may result from internal recycling processes, rather than water column uptake, supplying an increasing proportion of nutrient demand. Finally, part of the discrepancy between patterns of biomass stoichiometry and nutrient UE may be methodological, stemming from a potential disconnect between using pools (i.e. stoichiometry) vs. fluxes (i.e. rates) to assess nutrient UEs. Our estimates of nutrient UE were derived from instantaneous measurements of NEP and nutrient uptake during daylight hours when both fluxes are predicted to be high. Yet biomass stoichiometry measurements integrate element cycling over much longer time scales, suggesting that measures of nutrient UE may be best integrated over time periods that match the scale at which elements change in biomass (e.g., litterfall vs. leaf C:nutrient ratios; Vitousek, 1982). Clearly, additional research is needed to disentangle relationships between biomass stoichiometry and nutrient UE, as well as expectations about how warming and diel patterns of nutrient acquisition might influence nutrient UEs.

Anticipating how climate change affects stream ecosystems will require a broad array of research techniques that draw from theory, observation, and experimentation. Results from our experiment demonstrate that temperature had a strong influence on benthic biofilm structure and function, as well as coupled elemental cycles; however, it is unclear how these results apply to broader spatial and temporal scales (e.g. years to centuries; Osmond et al., 2004). Recent complementary research across a natural gradient of stream temperatures at Hengill suggests that our results generally parallel warming responses at larger, whole-stream scales. For instance, increased metabolism with warming has been observed along the natural thermal gradient (Demars et al., 2011; Perkins et al., 2012) and natural biofilm stoichiometry also appears to be relatively temperature-invariant (J.R. Junker \& W.F. Cross, Montana State University, unpublished data). These patterns suggest that results from our small-scale, short-term warming experiment may indeed predict large-scale, long-term responses to warming at this location. Nonetheless, additional studies are needed that explicitly compare the responses of short-term and small-scale experiments to observations across natural gradients of temperature or time (Dunne et al., 2004; O'Gorman et al., 2012). Geothermally heated ecosystems may be particularly well-suited for such investigations ( $\mathrm{O}^{\prime}$ Gorman et al., 2014).

We have demonstrated that warming can strongly influence the structure and function of biofilms in aquatic ecosystems. Our findings suggest that rates of Cbased fluxes in these habitats will increase with warm- ing due to a combination of decreased inhibition by cold temperature and increased $\mathrm{N}$ availability. However, our results also suggest that how these responses translate to other elemental cycles (e.g., $\mathrm{N}$ and $\mathrm{P}$ ) will depend upon environmental context (e.g., nutrient supply) and the functional traits of existing taxa. In oligotrophic streams, such as those studied here, the traits of dominant functional groups (i.e. cyanobacteria) may interact with ambient nutrient availability to strongly influence how the coupling of $C$ to other key elements will respond to warming. Future studies should simultaneously consider species functional traits, thermal performance, and temperature dependent variation in resource availability when studying effects of warming on fluxes of energy and elements in aquatic ecosystems.

\section{Acknowledgements}

This research was funded by the National Science Foundation (DEB-0949774 and DEB-0949726), with additional support from the Montana Institute on Ecosystems and St. Catherine University. JMH was also supported by the Icelandic Research Fund (i. Rannsóknasjóður) 141840-051 during manuscript preparation. We are deeply grateful to the Icelandic Institute of Freshwater Fisheries for providing laboratory space and logistical support. We would also like to thank Paula Furey, Chau Tran, our REU students Ellie Zignego (Montana State University) and David Hernandez (University of Alabama), and undergraduate students Aimee Ahles and Jackie Goldschmidt (St. Catherine University) for invaluable field and laboratory assistance.

\section{References}

Adrian R, O'Reilly CM, Zagarese $\mathrm{H}$ et al. (2009) Lakes as sentinels of climate change. Limnology and Oceanography, 54, 2283-2297.

Allen AP, Gillooly JF, Brown JH (2005) Linking the global carbon cycle to individual metabolism. Functional Ecology, 19, 202-213.

American Public Health Association (APHA) (2012) Inorganic nonmetallic constituents. In: Standard methods for the examination of water and wastewater, 22nd edn (eds Rice EW, Baird RB, Eaton AD, Clesceri LS), pp. 4-146-4-147. American Water Works Association, Maryland.

Árnason B, Theodorsson P, Björnsson S, Saemundsson K (1969) Hengill, a high temperature thermal area in Iceland. Bulletin of Volcanology, 33, 245-259.

Baligar VC, Fageria NK, He ZL (2001) Nutrient use efficiency in plants. Communications in Soil Science and Plant Analysis, 32, 921-950.

Battin TJ, Kaplan LA, Newbold JD, Hansen CME (2003) Contributions of microbial biofilms to ecosystem processes in stream mesocosms. Nature, 426, 439442

Baulch HM, Schindler DW, Turner MA, Findlay DL, Paterson MJ, Vinebrooke RD (2005) Effects of warming on benthic communities in a boreal lake: implication of climate change. Limnology and Oceanography, 50, 1377-1392.

Bott TL (2006) Primary production and community respiration. In: Methods in stream ecology, 2nd edn (eds Hauer FR, Lamberti GA), pp. 663-690. Academic Press, Massachusetts

Bozdogan H (1987) Model selection and Akaike's Information Criterion (AIC): the general theory and its analytical extensions. Psychometrika, 52, 345-370.

Brown JH, Gillooly JF, Allen AP, Savage VM, West GB (2004) Toward a metabolic theory of ecology. Ecology, 85, 771-1789.

Burkholder JM, Wetzel RG, Klomparens KL (1990) Direct comparison of phosphate uptake by adnate and loosely attached microalgae within an intact biofilm matrix Applied and Environmental Microbiology, 56, 2882-2890.

Capone DG (1993) Determination of nitrogenase activity in aquatic samples using the acetylene reduction procedure. In: Handbook of methods in microbial ecology 
(eds Kemp PF, Sherr BF, Sherr EB, Cole JJ), pp. 621-623. Lewis Publishers, Michigan.

Ceuterick F, Peeters J, Heremans K, De Smedt H, Olbrechts H (1978) Effect of high pressure, detergents and phospholipase on the break in the Arrhenius plot of Azotobacter nitrogenase. European Journal of Biochemistry, 87, 401-407.

Cottingham KL, Lennon JT, Brown BL (2005) Knowing when to draw the line: designing more informative ecological experiments. Frontiers in Ecology and the Environment, 3, 145-152.

Cox PM, Betts RA, Jones CD, Spall SA, Totterdell IJ (2000) Acceleration of global warming due to carbon-cycle feedbacks in a coupled climate model. Nature, 408 184-187.

Cross WF, Hood JM, Benstead JP, Huryn AD, Nelson D (2015) Interactions between temperature and nutrients across levels of ecological organization. Global Change Biology, 21, 1025-1040.

De Senerpont Domis LN, Van de Waal DB, Helmsing NR, Donk EV, Mooij WM (2014) Community stoichiometry in a changing world: combined effects of warming and eutrophication on phytoplankton dynamics. Ecology, 95, 1485 1495.

Demars BOL, Manson JR, Ólafsson JS et al. (2011) Temperature and the metabolic balance of streams. Freshwater Biology, 56, 1106-1121.

Dossena M, Yvon-Durocher G, Grey J, Montoya JM, Perkins DM, Trimmer M, Woodward G (2012) Warming alters community size structure and ecosystem functioning. Proceedings of the Royal Society, 279, 3011-3019.

Dunne JA, Saleska SR, Fischer ML, Harte J (2004) Integrating experimental and gradient methods in ecological climate change research. Ecology, 85, 904-916

Finzi AC, Austin AT, Cleland EE, Frey SD, Houlton BZ, Wallenstein MD (2011) Responses and feedbacks of coupled biogeochemical cycles to climate change: examples from terrestrial ecosystems. Frontiers in Ecology and the Environment, 9, 61-67.

Flett RJ, Hamilton RD, Campbell NER (1976) Aquatic acetylene-reduction techniques: solutions to several problems. Canadian Journal of Microbiology, 22, 43-51.

Friberg N, Dybkjær JB, Ólafsson JS, Gíslason GM, Larsen SE, Lauridsen TL (2009) Relationships between structure and function in streams contrasting in temperature. Freshwater Biology, 54, 2051-2068.

Frost PC, Evans-White MA, Finkel ZV, Jensen TC, Matzek V (2005) Are you what you eat? Physiological constraints on organismal stoichiometry in an unbalanced world. Oikos, 109, 18-28.

Gundmundsdottir R, Olafsson JS, Palsson S, Gislason GM, Moss B (2011) How will increased temperature and nutrient enrichment affect primary producers in subArctic streams? Freshwater Biology, 56, 2045-2058.

Hall SR, Smith VH, Lytle DA, Leibold MA (2005) Constraints on primary producer N: P stoichiometry along N: P supply ratio gradients. Ecology, 86, 1894 1904.

Hiremath AJ, Ewel JJ (2001) Ecosystem nutrient use efficiency, productivity, and nutrient accrual in model tropical communities. Ecosystems, 4, 669-682.

Holmes RM, Aminot A, Kérouel R, Hooker BA, Peterson BJ (1999) A simple and precise method for measuring ammonium in marine and freshwater ecosystems. Canadian Journal of Fisheries and Aquatic Science, 56, 1801-1808.

Howarth RW, Marino R, Cole JJ (1988) Nitrogen fixation in freshwater, estuarine, and marine ecosystems. 2. Biogeochemical Controls. Limnology and Oceanography, 33, 688 701

Hungate BA, Dukes JS, Shaw MR, Luo Y, Field CB (2003) Nitrogen and climate change. Science, 302, 1512-1513.

IPCC (2013) Summary for Policymakers. In: Climate Change 2013: the Physical Science Basis. Contribution of Working Group I to the Fifth Assessment Report of the Intergovernmental Panel on Climate Change (eds Stocker TF, Qin D, Plattner GK, Tignor M, Allen SK, Boschung J, Nauels A, Xia Y, Bex V, Midgley PM) pp. 3-29. Cambridge University Press, Cambridge.

Kaushal SS, Likens GE, Jaworski NA et al. (2010) Rising stream and river temperatures in the United States. Frontiers in Ecology and the Environment, 8, 461-466.

Kratz WA, Myers J (1955) Nutrition and growth of several blue-green algae. American Journal of Botany, 43, 282-287.

Lock MA, Wallace RR, Costerton JW, Ventullo RM, Charlton SE (1984) River epilithon: toward a structural-functional model. Oikos, 42, 10-22.

Lowe RL, LaLiberte GD (2006) Benthic stream algae: distribution and structure. In Methods in stream ecology, 2nd edn (eds Hauer FR, Lamberti GA), pp. 327-356. Academic Press, Massachusetts.

Luo Y, Su B, Currie SW et al. (2004) Progressive nitrogen limitation of ecosystem responses to rising atmospheric carbon dioxide. BioScience, 54, 731-739.
Lürling M, Eshetu F, Faassen EJ, Kosten S, Huszar VLM (2013) Comparison of cyanobacterial and green algal growth rates at different temperatures. Freshwater Biology, 58, 552-559.

Marcarelli AM, Baker MA, Wurtsbaugh WA (2008) Is in-stream $\mathrm{N}_{2}$ fixation an important $\mathrm{N}$ source for benthic communities and stream ecosystems. Journal of the North American Benthological Society, 27, 186-211.

Mulholland PJ, Tank JL, Sanzone DM, Wollheim WM, Peterson BJ, Webster JR, Meyer JL (2000) Nitrogen cycling in a forest stream determined by a ${ }^{15} \mathrm{~N}$ tracer addition. Ecological Monographs, 70, 471-493.

Nifong RL, Cohen MJ, Cropper WP Jr (2014) Homeostasis and nutrient limitation of benthic autotrophs in natural chemostats. Limnology and Oceanography, 59, 20102111.

O'Brien JM, Dodds WK (2008) Ammonium uptake and mineralization in prairie streams: chamber incubation and short-term nutrient addition experiments. Freshwater Biology, 53, 102-112.

O'Gorman EJ, Pichler DE, Adams G et al. (2012) Impacts of warming on the structure and functioning of aquatic communities: individual- to ecosystem-level responses. Advances in Ecological Research, 47, 81-176.

O'Gorman EJ, Benstead JP, Cross WF et al. (2014) Climate change and geothermal ecosystems: natural laboratories, sentinel systems, and future refugia. Global Change Biology, 20, 3291-3299.

Osmond B, Ananyev G, Berry J et al. (2004) Changing the way we think about global change research: scaling up in experimental ecosystem science. Global Change Biology, 10, 393-407.

Paerl HW, Huisman J (2008) Blooms like it hot. Science, 320, 57-58.

Parmesan C, Yohe G (2003) A globally coherent fingerprint of climate change impacts across natural systems. Nature, 421, 37-72.

Pastor J, Bridgham SD (1999) Nutrient efficiency along nutrient availability gradients. Oecologia, 118, 50-58.

Perkins DM, Yvon-Durocher G, Demars BOL et al. (2012) Consistent temperature dependence of respiration across ecosystems contrasting in thermal history. Global Change Biology, 18, 1365-2486.

R Core Team (2013) R: a language and environment for statistical computing. R Foundation for Statistical Computing, Vienna, Austria. Available at http://www.R-project.org/ (accessed 1 February 2013).

Rasmussen JJ, Baattrup-Pedersen A, Riis T, Friberg N (2011) Stream ecosystem properties and processes along a temperature gradient. Aquatic Ecology, 45, 231-242.

Rhee J-Y, Gotham IJ (1981) The effect of environmental factors on phytoplankton growth: temperature and the interactions of temperature with nutrient limitation. Limnology and Oceanography, 26, 635-648.

Sardans J, Rivas-Ubach A, Peñuelas J (2012) The C:N: P stoichiometry of organisms and ecosystems in a changing world: a review and perspectives. Perspective in Plant Ecology, Evolution, and Systematics, 14, 33-47.

Schlesinger WH, Cole JJ, Finzi AC, Holland EA (2011) Introduction to coupled biogeochemical cycles. Frontiers in Ecology and the Environment, 9, 5-8.

Scott JT, Marcarelli AM (2012) Cyanobacteria in freshwater benthic environments. In Ecology of cyanobacteria II: Their diversity in space and time (ed. Whitton BA), pp. 271-289. Springer, New York.

Shurin JB, Clasen JL, Greig HS, Kratina P, Thompson PL (2012) Warming shifts topdown and bottom-up control of pond foodweb structure and function. Philosophical Transactions of the Royal Society, 367, 3008-3017.

Sistla SA, Schimel JP (2015) Stoichiometric flexibility as a regulator of carbon and nutrient cycling in terrestrial ecosystems under change. New Phytologist, 196, 68 45.

Sun J, Liu D (2003) Geometric models for calculating cell biovolume and surface area for phytoplankton. Journal of Plankton Research, 25, 1331-1346.

Taylor BW, Keep CF, Hall RO, Koch BJ, Tronstad LM, Flecker AS, Ulseth AJ (2007) Improving the fluorometric ammonium method: matrix effects, background fluorescence, and standard additions. Journal of the North American Benthological Society, 26, 167-177.

Vitousek PM (1982) Nutrient cycling and nutrient use efficiency. The American Naturalist, 119, 553-572.

Vitousek PM, Cassman K, Cleveland C et al. (2002) Towards an ecological understanding of biological nitrogen fixation. Biogeochemistry, 57, 1-45.

Webb CT, Hoeting JA, Ames GM, Pyne MI, Poff NL (2010) A structured and dynamic framework to advance traits-based theory and prediction in ecology. Ecology Letters, 13, 267-283.

Webster JR, Mulholland PJ, Tank JL et al. (2003) Factors affecting ammonium uptake in streams - an inter-biome perspective. Freshwater Biology, 48, 1329 1352. 
Welter JR, Benstead JP, Cross WF, Hood JM, Huryn AD, Johnson PW, Williamson TJ (2015) Does $\mathrm{N}_{2}$-fixation amplify the temperature dependence of biofilm metabolism? Ecology, 96, 603-610.

Woodward G, Perkins DM, Brown LE (2010) Climate change and freshwater ecosystems: impacts across multiple levels of organization. Philosophical Transactions of the Royal Society, 365, 2093-2106.

Yvon-Durocher G, Allen AP (2012) Linking community size structure and ecosystem functioning using metabolic theory. Philosophical Transactions of the Royal Society, 367, 2998-3007.

Yvon-Durocher G, Jones JI, Trimmer M, Woodward G, Montoya JM (2010a) Warming alters the metabolic balance of ecosystems. Philosophical Transactions of the Royal Society, 365, 2117-2126.

Yvon-Durocher G, Montoya JM, Trimmer M, Woodward G (2010b) Warming alters the size spectrum and shifts the distribution of biomass in aquatic ecosystems. Global Change Biology, 17, 1681-1694.

\section{Supporting Information}

Additional Supporting Information may be found in the online version of this article:

Table S1. Results from a one-way ANOVA with Tukey's honestly significant difference (HSD) test of pairwise temperature treatment comparisons.

Figure S1. Time series of daily mean temperature treatments.

Figure S2. Experimental channel array in operation. 